Citation: Demska, O., \& Levchuk, P. (2020). The urbanonimia of Ukraine in the context of decommunization. Cognitive Studies / Études cognitives, 2020(20), Article 2280. https://doi.org/10.11649/cs.2280

\section{ORYSIA DEMSKA}

Chairman of the National Commission on State Language Standards, Kyiv, Ukraine https://orcid.org/0000-0002-8915-0456 ordemska@gmail.com

\section{PAVLO LEVCHUK}

Institute of Slavic Studies, Polish Academy of Sciences, Warsaw, Poland https://orcid.org/0000-0001-7865-6833

pavlo.levchuk@ispan.waw.pl

\title{
THE URBANONIMIA OF UKRAINE IN THE CONTEXT OF DECOMMUNIZATION
}

\begin{abstract}
This article concerns the changing situation regarding toponyms in Ukraine, from the country's regaining of independence to the present day. The article identifies two waves of decommunization. The first occurred between the regaining independence in 1991 and 1995. The second wave began with the Revolution of Dignity in 2013-2014 and continues to this day. In the second part of the article, toponyms connected with Poland are presented and the reasons behind their creation are explained.
\end{abstract}

Keywords: the Ukrainian language; the Polish language; toponymy; decommunization

\section{Background}

The history of naming objects of urban space in Europe began in the mid-eighteenth century, when the Swedish post office decided to facilitate their work by introducing the numbers of buildings and erecting street signs. Following this example, other European capitals started to apply the idea of a city layout using the names of urban objects. In 1762, the King of Sweden issued a decree ordering street signs to be placed at the intersections of important streets in Stockholm. In 1765, a law was adopted in London requiring local governments to number buildings and name streets. The issue of numbering buildings was discussed at least twice in Berlin, for the first time in 1789, when the mayor suggested numbering buildings, and the second time in 1797, when the decision was taken to number buildings in Berlin, not only on the central streets, but also on peripheral ones. In 1803, Vienna joined the above-mentioned cities, followed by Paris in 1806. At that time, they were the first cities to legally regulate the naming of urban space. Despite the fact that Paris did not introduce the city naming system until 1806, it was the French Revolution that had first used the issue of naming streets, alleys and squares for political purposes and, as Maoz Azaryahu rightly points out, the practice of showing respect through the names of streets and squares in the capital became a component of French political symbolism and quickly found supporters in other European capitals (cf. Azaryahu, 1996, p. 313).

The tradition of naming urban space was part of a process which, over two centuries, transformed from what would seem to be an simple procedure for naming streets into a symbolic and 
ideological value, creating and implementing the ideas of toponymy and the politics of memory. Bearing such great importance, street names were at the centre of powerful struggles during periods of social transformation, and were even the hallmark revolutions themselves. Henri Lefebvre rightly observes that the revolution that does not produce new space has not been successful. In fact, it has suffered defeat because it has not changed life itself, merely its ideology, institutions or politics. Social transformation, in order to be truly revolutionary, must have creative potential in its impact on everyday routine, language and space (cf. Lefebvre, 1991, p. 54).

The practice of naming urban space has been at the centre of interest in linguistic research since the end of the $20^{\text {th }}$ century. It is worth mentioning the work of post-totalitarian urban space researchers, namely Ivana Crljenko, Duncan Light, Emilia Palonen, Liubomyr Belej and others (cf. Beler̆, 2015; Crljenko, 2012; Light, 2004; Palonen, 2008); Yeoh Brenda has studied the examples of naming in Singapore (cf. Yeoh, 1992, 1996), Stephen Jett has researched the nomination of ethnic elements (cf. Jett, 2011). The specificity of such research is that these studies go beyond the scope of linguistics and become interdisciplinary research, such as the work of Andrea Bölcskei, Andrea Cantile, Orysia Demska, Hattice Ayatac and Selime Araz, Jaworski and Thurlow (cf. Ayatac \& Araz, 2016; Bölcskei, 2014; Cantile, 2016; Demska, 2019; Jaworski \& Thurlow, 2010).

Treating toponym change as an important part of social, political and geopolitical change, this article will attempt to examine the Ukrainian practice of changing the names of urban objects, since the collapse of the USSR to the present day, especially taking into account toponyms of Polish origin.

\section{Historical background}

For Ukraine, the beginning of the farewell to the Soviet world began with regaining independence in 1991. Since then, there have been two waves of toponymic changes: the first occurred between 1991 and 2000 and the second started in 2014 and is still in progress. The two-stage nature of toponymic changes perfectly reflects the nature of Ukraine's farewell to the Soviet empire: a long transition from the Soviet to the post-Soviet world, followed by the exit from the post-Soviet reality.

The first wave followed the collapse of the USSR and generally took place in the west of the country. The changes had a historical background, particularly connected to local history, and the initiators of the changes were local intellectual elites, who focused their attention mainly on the inner space of towns and cities and less often on other geographical features. Characteristic of this period were the following practices: counter-naming, i.e. the change of Soviet names to Ukrainian ones, often to those which were banned or not approved of before 1991; reminding or restoration, i.e. restoring historical names; and the legitimization of usus: changing oeconyms according to traditional forms of local names. A classic example of counter-naming is the change of Lenin Street into Shevchenko Street; reminding or restoration of a former historical name: Voroshilovgrad, which changed its name to Luhansk; and the legitimization of usus, mainly implemented within the borders of the oeconyms Slavsko-Slavske (Славсъко - Славсъке) in the Lviv Oblast (cf. Demska, 2016, pp. 603-604).

Social, economic and political changes in Ukraine determined the time frame of the first wave of toponymic transformations. On 24 August 1991, the Supreme Soviet (literally: Supreme Council) of the UkrSSR adopted the Act of Independence of Ukraine, which won support through a referendum on 1 December 1991, in which $90.32 \%$ of Ukrainians decided to establish an independent Ukraine. On the same day, the first presidential election took place, which was won by Leonid Kravchuk. On 8 December 1991 in the Belavezha Forest, and then on 21 December in Alma-Ata, the leaders of Ukraine, Belarus and Russia confirmed that the USSR had ceased to exist. However, as early as 1994 Leonid Kuchma became the president of Ukraine. He expressed pro-Russian views, for instance he promised to officially introduce bilingualism in Ukraine, although later this trend changed. In addition, in the economic sphere between 1991 and 1996, before the introduction of 
the hryvnia, there was hyperinflation and before 1999 an economic recession occurred. During this period Ukraine lost $60 \%$ of its GDP. In the years 1992-1997, voucher privatization took place, which contributed to the creation and empowerment of Ukrainian oligarchs. Ukraine had become a post-Soviet state, resulting in the arrested development of democracy in the country. For this reason, the process of changing toponyms from Soviet to Ukrainian ones ended in 1995, i.e. a year after the election of Leonid Kuchma as president. In the period from 1991 to 1996, the Supreme Soviet changed the names of 463 places, the most in 1995 (139), and the least in 1996 (only 1). In Lviv Oblast - 184 place names were changed, in the Transcarpathian region - 125; in the remaining oblasts fewer than 100 toponyms were changed. Place names in the Sumy, Kharkiv, Kherson, Chernihiv and Crimea oblasts remained almost unchanged, with only 1 change noted. As a result, in 2012 the 100 most frequent names of main streets in Ukrainian towns and cities and towns included Lenin - 4 463, Radianska (Soviet) - 954, Myru (Peace) - 616 and Zhovtneva (October) - 529 (cf.: 20 rokiv Nezalezhnosti: Lienin vse niiak ne Goodbye!, 2012). However, not only are politicians to blame for slowing down the transformation of toponyms. The end of the $20^{\text {th }}$ century in Ukraine was a period of economic difficulty and hardship, when people had to think about how to survive. The economic and political situation became more important than changing toponyms.

After the end of the first wave of decommunization in 1995, only individual cases of name changes occurred until 2000 before stopping completely. Even the Orange Revolution in 20042005 did not change this state of affairs, and even confirmed Lefebvre's thesis about "the failure of the revolution that did not create its own space". This is evidenced by the above-mentioned street name ranking from 2012 and the fact that in 2014 the ranking of popularity of oeconyms was as follows: Red - October - Lenin - Kirov - Soviet - Komsomol ( Червоний - Жовтень Ленін - Кіров - Радянсъка - Комсомольсъка) (Demska, 2016, pp. 604, 606-607).

\section{Results}

Only after the victory of the Revolution of Dignity (2013-2014) in 2014 did the second wave of toponymic transformation begin, and it is still ongoing today. It should be noted that the second wave is not only the result of decommunization, but that it plays a much more important role, namely that it is an important instrument. Contemporary naming practices are now supported by legislation. Of the four decommunization laws of 09.04.2015 No. 317-VIII proposed by the Ukrainian Institute of National Remembrance, the most important for toponyms is the Law Pro zasudzhennia komunistychnoho ta natsional-sotsialistychnoho (natsystskoho) totalitarnykh rezhymiv v Ukraini ta zaboronu propahandy yikhnoi symvoliky (of 08.08.2015). This legislative basis has ensured that the second wave is a nationwide phenomenon, and it aims to change are all types of toponyms, starting from street names and ending with peripheral towns. In addition, it should be noted that the nature of modern toponymic practices proves that the Revolution of Dignity is winning, as it manifests its creative potential and changes space, while suggesting that proper nouns are a symbolic instrument of power.

The toponymic activity of the second wave includes three currents from the first wave: counternaming, restoration, and legitimization of usus, but very importantly there is a new naming trend associated with the commemoration of modern Ukrainian heroes, including world-renowned and female names. By using the anthroponyms of modern heroes to immortalize them, the process of establishing a national geopolitical space, connected by a single historical axis, takes place, as memorable street names together with monuments and museums are not only a testimony of a certain version of history, but an active participant in the process of creating a common future (Azaryahu, 1996, p. 312). Changes in individual cities are becoming the subject of interest of researchers (Fernos, 2018; Hrymashevych, 2016; Males, 2016). 
As part of recent decommunization practices, counter-naming has become less and less frequent. Examples include: In Vinnytsia, Korniichuk Street was changed to Oles Honchar ${ }^{1}$, Pionerska - Plastova, Chervonykh kursantiv - Heroiv Krut ${ }^{2}$; in Kyiv, Bozhenko Street was changed to Guillaume de Beauplan, Shchors to Yevhen Konovalets ${ }^{3}$, Kollontai to Dmytro Yavornytskyi ${ }^{4}$; in Dnipro - 55 years of VLKSM ${ }^{5}$ to Plastivska, Bielinskyj to Izmail Sreznevskyi ${ }^{6}$; in Cherkasy, Vatutin Street was changed to Hetman Sahaidachnyi. ${ }^{7}$ Although the practice of counter-naming often provokes conflicts, it should not be ceased since it has a special impact on educating society, fostering public discussion and encouraging Ukrainians to actively create a common history and a new public space.

Currently, the practice of reminding (restoration) is used with increasing frequency. The practice can be divided into two models. The first model is the restoration of the historical names of specific geographical features. For example, the city of Artemivsk (Donetsk Oblast) regained its old name, Bakhmut, the village of Kirovske (Donetsk Oblast) reverted to Dianivka, the village of Illicha (Kharkiv region) reverted to Nova Kozacha, the village of Radianske (Kharkiv region) reverted to Hrafske, the village of Chervona Buda (Chernihiv region) reverted to Romanivska Buda. Old street names were also restored, in Dnipro Baidakivska, Soborna, Lebedynska, Troitska; in Kharkiv Panteleimonivska, Seminarska; in Cherkasy Mytnytska, Tatynetska and others. The second model is the commemoration of Ukrainian history through the use of names of previously banned or forgotten historical figures. For example, in Dnipro, Kherson, Chernivtsi, Bila Tserkva, Kryzhopil, and Makariv, Vasyl Stus ${ }^{8}$ Street appeared. In Kyiv, Dnipro, and Fastiv, Volodymyr Vynnychenko ${ }^{9}$ Street appeared. In Dnipro, Rivne, Uzhorod, and Nizhyn, Volodymyr Ivasiuk ${ }^{10}$ Street appeared. In Dnipro, Zhytomyr, Vinnitsa, Kherson, Uzhgorod, Bila Tserkva, Uman, Pryluky, and Kryzhopil, Heroiv Krut Street appeared, being one of the names most commonly banned by the communist authorities along with Ivan Mazepa ${ }^{11}$ Street, which can now be found in Kyiv, Dnipro, Zhytomyr, Poltava, Chernihiv, Chernivtsi, Bila Tserkva, Uman, Fastiv, Pryluky, Nizhyn, Kryzhopil, and Makariv. An interesting example of the legitimacy of usage is when the city of Dnipropetrovsk became Dnipro in 2016, as the new official name already existed in usage.

The origins of the new naming practices lie Ukraine's turbulent recent history, namely the Revolution of Dignity, volunteer activists, the annexation of Crimea, and the armed UkrainianRussian conflict in parts of the Donetsk and Luhansk oblasts. Hence the street names of Heroiv Maidanu ${ }^{12}$, Heroiv ATO ${ }^{13}$, Heroiv Donetskoho aeroportu ${ }^{14}$, Volonterska / Volonteriv / Volonteriv Frontu (Волонтерсъка / Волонтерів / Волонтерів Фронту) general Momot ${ }^{15}$, general Kulchytskyi $^{16}$, Starshyi leitenant Podolianchuk ${ }^{17}$, Isa Munaiev ${ }^{18}$, molodshyi serzhant Karavaiskyi ${ }^{19}$ (all

${ }^{1}$ (1918-1995), real name Oleksandr Bilychenko, Ukrainian poet and literary critic.

${ }^{2}$ The battle took place on 16 January 1918. Students were trying to prevent the Red Army from attacking Kyiv.

3 (1891-1938), ideologist of Ukrainian nationalism.

4 (1855-1940), historian, archaeologist, lexicologist and writer.

${ }^{5}$ Komsomol, Russ. Vsesoyuznyiy leninskiy kommunisticheskiy soyuz molodyozhi. [All-Union Leninist Young Communist League].

${ }^{6}(1812-1880)$, Slavicist and ethnographer.

7 (1570-1622), hetman of Registered Cossacks, one of the greatest Cossack leaders of the $17^{\text {th }}$ century.

8 (1938-1985), poet, translator and representative of the Ukrainian culture movement of the 1960s. In Warsaw in 2017 Vasyl Stuts square was named in his honour.

${ }^{9}(1880-1951)$, politician, writer and artist.

10 (1949-1979), composer and writer.

${ }^{11}$ (1639-1709), nobleman, diplomat and hetman of Left-bank Ukraine in 1687-1709.

${ }^{12}$ People who died during the Revolution of Dignity in January 2014.

${ }^{13}$ People who died as a result of the anti-terrorist operation, which lasted from 2014 to 2018.

${ }^{14}$ Soldiers who defended Donetsk airport.

${ }^{15}$ (1965-2014), general killed during the anti-terrorist operation.

${ }^{16}(1963-2014)$, general killed during the anti-terrorist operation.

${ }^{17}$ (1991-2014), commander of the special unit of the $3^{\text {rd }}$ Regiment (Kirovohrad), died during the defence of the Donetsk airport.

${ }^{18}$ Commander of the international battalion that fought for the independence of Ukraine (Dzhokhar Dudayev Battalion).

${ }^{19}(1990-2014)$, commander of a unit of the $3^{\text {rd }}$ regiment, killed at the Izvaryne border crossing point. 
of whom died during the Russian-Ukrainian military conflict). A unique feature of creating new toponyms in Ukraine is the use of well-known names from world history, religious names, and female names. For example, Dzhuzeppe Haribaldi Street appears in Dnipro, and Andrii Pervozvannyi ${ }^{20}$ Street can be found in Vinnytsia. Other examples include: Svyatykh Kyryla ta Mefodiia in Kherson; Sviatyi Mykolai in Zaporizhzia; Velykopokrovska ${ }^{21}$ in Fastiv; Novoprechystenska in Cherkasy; Mytropolyt Petro Mohyla ${ }^{22}$ in Vinnytsia; Patriarkh Volodymyr Romaniuk ${ }^{23}$ and Mytropolyt Volodymyr Sabodan ${ }^{24}$ in Kyiv; Patriarkh Mstyslav (Skrypnyk) ${ }^{25}$ in Kyiv and Poltava; Andrii Sheptytskyi ${ }^{26}$ in Kyiv, Mykolaiv, Rivne, Khmelnytsky, Fastiv, and Tavriysk; Liuteranska in Kherson; Synahohy in Chernivtsi; Monastyrska in Zhytomyr, Cherkasy, Vinnytsia; Kniahynia Olha ${ }^{27}$ in Dnipro, Bila Tserkva, Fastiv, Hoshcha, and Makariv; Olena Teliha ${ }^{28}$ in Dnipro, Zhytomyr, Poltava, Zaporizhzia, Cherkasy, Uman, and Hoshcha; Anna Yaroslavna ${ }^{29}$ in Kyiv and Dnipro; Vira Kholodna ${ }^{30}$ in Poltava; Kvitka Tsisyk ${ }^{31}$ in Kyiv and Khmelnytsky; Solomia Krushelnytska ${ }^{32}$ in Dnipro and Tavriysk; Liudmyla Hurchenko ${ }^{33}$ in Kharkiv; Maria Hrichenko ${ }^{34}$ in Dnipro and Uman; Maria Pryimachenko ${ }^{35}$ in Kyiv, Dnipro, and Khmelnytsky; Olena Pchilka ${ }^{36}$ in Dnipro, Vinnytsia, and Poltava.

The second wave of toponym change applies to Polish names as well, which indicates a shift from pro-Russian to pro-European tendencies. Before 2014, one could find Polish street names in Ukraine, including Adam Mickiewicz Street or Square in Lviv, Kyiv, and Rivne; Juliusz Słowacki Street in Lviv, Kremenets, Lutsk and Rivne; Nicolaus Copernicus Street in Lviv, Kyiv, Lutsk, and Rivne; Frederic Chopin Street in Ivano-Frankivsk, Lviv, Lutsk, and Kolomyia. It is also worth mentioning Cathedral Square in Lviv and Cathedral Street in Lutsk.

The most common practice in relation to Polish activists on a local scale was to commemorate people who were connected with particular towns. In Zhytomyr there is now a street named after St. Zygmunt Felinski ${ }^{37}$, who lived in Zhytomyr when he was a child. One can find Josef Hofmann Street in Poltava, and Józef Lobodowski Street in Lutsk, named after the Polish poet who was active in the city before World War II.

Vinnytsia is the city where most Polish toponyms have appeared, mostly in the form of the restoration of former street names. Examples include Monastyrska Street, which separated the former Jesuit, Dominican and Orthodox monasteries, and Grocholscy Street, commemorating social activists in Podolia, especially in Vinnytsia. Vinnytsia has commemorated Joseph Conrad ${ }^{38}$ and Władysław Horodecki ${ }^{39}$ by naming streets after them. Marceliusz Wysokinski Street is especially

\footnotetext{
${ }^{20}$ Andrew the Apostle.

${ }^{21}$ Pokrova Presviatoi Bohorodytsi, religious and public holiday.

22 (1596-1647), Orthodox bishop, Metropolitan of Kyiv and saint.

23 (1925-1995), Orthodox bishop, Patriarch of Kyiv from 1993 to 1995.

${ }^{24}$ (1935-2014), Orthodox bishop, from 1992 to 2014 Metropolitan of the Orthodox Church in Ukraine (Moscow Patriarchate).

25 (1898-1993), Patriarch of the Ukrainian Orthodox Church for the diaspora.

${ }^{26}$ (1865-1944), Greek Catholic priest, in 1899-1900 Bishop of Stanyslaviv, 1900-1944 Metropolitan Archbishop of Lviv and Halych, bishop of Kamyanets-Podilskyi.

${ }^{27}$ (910-969), mother of St. Vladimir, who baptised Rus; a saint in both the Orthodox and Catholic churches.

28 (1907-1942), poet, literary critic and political activist.

29 (1032-1075), daughter of Yaroslav the Wise, Rus princess, queen of France of the Rurik dynasty.

$30(1893-1919)$, film actress.

31 (1953-1998), American singer of Ukrainian origin (female).

32 (1872-1952), Ukrainian singer (soprano) and teacher (female).

${ }^{33}$ (1935-2011), Soviet and Russian film and theatre actress and stage singer; the most popular Soviet TV star of the eighties. She was born in Kharkiv.

${ }^{34}(1863-1928)$, writer, translator, lexicographer and teacher (female).

35 (1909-1997), Ukrainian painter (female).

36 (1849-1930), Ukrainian writer, literary critic, publisher, ethnographer and folklorist; mother of Lesya Ukrainka.

37 (1822-1895), Polish bishop.

${ }^{38} \mathrm{He}$ often visited the noblemen who lived in the Vinnytsia area.

${ }^{39}$ (1863-1930), architect, representative of modernism, creator of St. Nicholas Cathedral and the Karaite Kenesa in Kyiv, the Shah's Palace and railway station in Teheran, and the Potocki family crypt in Pechera.
} 
worth mentioning. It commemorates a priest who until 11 years after the end of World War II was the parish priest of Our Lady of the Angels in Vinnytsia.

Catholic-related toponyms are also experiencing a renaissance. Before the new wave of changes in toponyms, Kościelna (Church) Street was only to be found in Kyiv. Now it can also be found in Fastiv. Deputies in Fastiv have also commemorated a local priest, Fr. Zygmunt Kozar, by naming a street after him. Among the new toponyms are streets dedicated to Pope John Paul II, who visited Ukraine in 2001. Streets named after him can be found in Kyiv, Zhytomyr and Khmelnytskyi.

Four streets dedicated to people associated with the Ukrainian capital have appeared in Kyiv: Janusz Korczak Street, family Idzikowski Street (named after a $19^{\text {th }}$ century family of Polish book publishers), Wilhelm Kotarbiński Street (named after a Polish painter), and Igor Sikorski ${ }^{40}$ Street, which can also be found in Vinnytsia. In Zhytomyr and Khmelnytskyi, President Lech Kaczyński, the Polish president who died tragically near Smoleńsk, has been commemorated. Previously, Lech Kaczyński Street was only to be found in Odesa.

Further examples of street names that have connections with Poland include instances of counter-naming, such as General Bezruchko Street, which can be found in Kyiv, Vinnytsia and Rivne. This figure is important for Poland because in 1920 he was the commander of the $6^{\text {th }}$ Sich Rifle Division, which contributed to the defeat of the Budyonny Army near Zamość, which had a decisive impact on the defence of Poland and Europe against the Bolshevik invasion. In Rivne, this street previously carried the name of the Serb Oleko Dundych, who was one of the red commanders of the $1^{\text {st }}$ Horse Army and who died during the Rivne attack in the Polish-Bolshevik war. Another street in Rivne, namely Battle of Orsha Street, also deserves to be mentioned. The Battle of Orsha took place on 8 September 1514, during the Lithuanian-Muscovite war of 15121522 between the Lithuanian-Polish forces, under the command of the Grand Hetman of Lithuania Prince Konstanty Ostrogski, and the Muscovite army under the command of Ivan Czeladnin. One can find contemporary echoes of cooperation between Rivne and Polish cities, as evidenced by Lubelska Street.

\section{Conclusion}

To summarise, it should be noted that it is only the second wave of toponym change that has led Ukraine to real independence. Modern Leninopad (removing Lenin monuments from city squares in Ukraine) and changing the names of cities and streets will lead the country to true freedom. The state authorities have declared a change of attitude from pro-Russian to pro-European. There are still a few remnants of the UkrSSR in Ukraine, namely Soviet and post-Soviet culture, which still dominates in some regions of the country, and the Russian language, which often performs the function of a official language, despite the fact that in the constitution it is solely the language of a national minority.

\section{References}

Ayatac, H., \& Araz, S. (2016). Influences of renaming streets on urban memory: The case of Turkey. International Planning History Society Proceedings: 17th IPHS Conference, History-Urbanism-Resilience, 17-21 July, 17(4), 37-45. https://doi.org/10.7480/IPHS.2016.4.1280

Azaryahu, M. (1996). The power of commemorative street names. Environment and Planning D: Society and Space, 14(3), 311-330. https://doi.org/10.1068/d140311

\footnotetext{
${ }^{40}$ In the times of the Rzeczpospolita (Polish-Lithuanian Commonwealth) they were a well-known noble family in Volhynia; aircraft designer, creator of the first multi-engine aircraft and first helicopters. Moreover, Kyiv Polytechnic Institute, which is in a leading position in many rankings among higher education institutions in Ukraine, bears the name of Igor Sikorsky.
} 


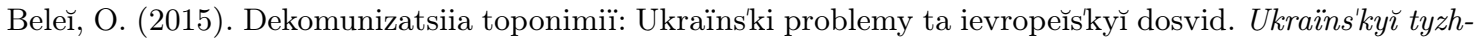
den', 2015(16-17), 12-15.

Bölcskei, A. (2014). Culture dependent toponym types: The concept of SETTLEMENT in different cultures. Els noms en la vida quotidiana: Actes del XXIV Congrés Internacional d'ICOS sobre Ciències Onomàstiques, 2014, 1010-1018. https://doi.org/10.2436/15.8040.01.105

Cantile, A. (2016). Place names as intangible cultural heritage: Potential and limits. In A. Cantile \& H. Kerfoot (Eds.), Place names as intangible cultural heritage (pp. 11-16). IGMI.

Crljenko, I. (2012). The renaming of streets and squares in post-socialist Croatian town. Mova $i$ suspil' stvo / Language and society, 2012(3), 230-241.

Demska, O. (2016). Suchasnyı̌ toponimnyı̆ landshaft Ukraïny: Mizh pamiattiu i spohadom. Slavia Orientalis, 65(3), 601-611.

Demska, O. (2019). Street name as a cultural code. In D. C. Chyk, O. M. Demska, I. I. Dmytriv, \& M. Y. Fedurko, Development trends of philological sciences: Collective monograph (pp. 20-42). LihaPres. https://doi.org/10.36059/978-966-397-127-8/20-38

20 rokiv Nezalezhnosti: Lienin vse niiak ne Goodbye! (2012). Texty.org.ua. https://texty.org.ua/ articles/37123/20_rokiv_Nezalezhnosti_Lenin_vse_nijak_ne-37123/

Fernos, I. (2018). Vplyv protsesiv dekomunizatsiï na systemu urbanomiv m. Umani. Visnyk Universytetu imeni Al'freda Nobelia: Seriia "Filolohichni nauky", 2018(2(16)), 299-304. https://doi.org/10. 32342/2523-4463-2018-2-16-28

Hrymashevych, H. (2016). Urbanonimiia ZHytomyra v konteksti dekomunizatsiï. Mova: Klasychne moderne — postmoderne: Zbirnyk naukovykh prats', 2016(2), 53-61. http://ekmair.ukma.edu.ua/ handle/123456789/11408

Jaworski, A., \& Thurlow, C. (2010). Introducing semiotic landscapes. In A. Jaworski \& C. Thurlow (Eds.), Semiotic landscapes: Language, image, space (pp. 1-40). Continuum.

Jett, S. C. (2011). Landscape embedded in language: The Navajo of Canyon de Chelly, Arizona, and their named places. In D. M. Mark, A. G. Turk, N. Burenhult, \& D. Stea (Eds.), Landscape in language: Transdisciplinary perspectives (pp. 327-342). John Benjamins Publishing Company. https: //doi.org/10.1075/clu.4.16jet

Lefebvre, H. (1991). The production of space (D. Nicholson-Smith, Trans.). Basil Blackwell.

Light, D. (2004). Street names in Bucharest, 1990-1997: Exploring the modern historical geographies of post-socialist change. Journal of Historical Geography, 30(1), 154-172. https://doi.org/10.1016/ S0305-7488(02) 00102-0

Males, L. (2016). Decommunization of the capital: Changes in urbanonymy (Methods and the first results). Visnyk V. N. Karazin Kharkiv National University: Series "Sociological Studies of contemporary society: Methodology, theory, methods", 36, 62-67. https://periodicals.karazin.ua/ssms/article/ view/ 6538

Palonen, E. (2008). The city-text in post-communist Budapest: Street names, memorials, and the politics of commemoration. GeoJournal, 73, 219-230. https://doi.org/10.1007/s10708-008-9204-2

Yeoh, B. (1992). Street names in colonial Singapore. Geographical Review, 82(3), 313-322. https://doi . org/10.2307/215354

Yeoh, B. (1996). Street-naming and nation-building: Toponymic inscriptions of nationhood in Singapore. Area, 28(3), 298-307.

This work was financed by the Polish Ministry of Science and Higher Education.

Orysia Demska declares that she has no competing interests. Pavlo Levchuk is the Editorial Secretary of the journal.

This research was supported by the CLARIN-PL ${ }^{41}$ research infrastructure.

All the authors participated equally in preparing conception and academic editing of this article.

This is an Open Access article distributed under the terms of the Creative Commons Attribution 3.0 PL License (http://creativecommons.org/licenses/by/3.0/pl/), which permits redistribution, commercial and noncommercial, provided that the article is properly cited.

\footnotetext{
${ }^{41}$ http://clarin-pl.eu
} 
Publisher: Institute of Slavic Studies, Polish Academy of Sciences

Publishing History: Received 2020-04-21; Accepted 2020-05-14; Published 2020-12-23. 